\title{
Peningkatan Produksi Kakao melalui Penerapan Teknologi Kakao Sehat pada Kelompok Tani "Wonga Mengi" di Desa Kedebodu, Kecamatan Ende Selatan, Kabupaten Ende, Propinsi Nusa Tenggara Timur
}

\author{
Sri Wahyuni ${ }^{1}{ }^{*}$, Josina I.B. Hutubessy ${ }^{1}$, dan Ferdinandus Lidang Witi $^{2}$ \\ ${ }^{1)}$ Program Studi Agroteknologi Universitas Flores, Ende-Nusa Tenggara Timur, Indonesia, \\ ${ }^{2)}$ Program Studi Teknologi Informasi Universitas Flores, Ende-Nusa Tenggara Timur, Indonesia \\ *Coresponding Author: sriwahyuni4611@gmail.com
}

\begin{abstract}
ABSTRAK
Desa Kedibodu terletak $12 \mathrm{~km}$ dari ibu Kota Kabupen Ende, yang sebahagian penduduknya bermata pencaharian sebagai petani kakao. Luas lahan rata-rata petani kakao adalah \pm 2 ha/orang dengan produktivitas rata-rata sebesar $140 \mathrm{~kg} / \mathrm{ha}$ yang sangat jauh dari potensi kakao ideal yaitu 1.150 $2.000 \mathrm{~kg} / \mathrm{ha}$. Kondisi tersebut disebabkan karena usia tanaman kakao yang tidak produktif lagi, kurangnya perawatan serta tingginya serangan hama dan penyakit. Pengabdian ini bertujuan untuk meningkatkan pengetahuan dan keterampilan petani kakao dalam menerapkan teknologi kakao sehat agar produksi tanaman kakao khususnya di kelompok tani "Wonga Mengi" di desa Kedibodu dapat ditingkatkan. Matode yang digunakan adalah metode partisipatif dalam bentuk sekolah lapang dengan memberikan materi dan penerapannya secara langsung di kebun. Terdapat dua kegiatan utama program yaitu pemberian bantuan langsung berupa bibit kakao unggul dalam bentuk stek ataupun entris dan alat pangkas serta melakukan pendampingan dalam penerapan teknologi kakao sehat. Setelah dilakukan pendampingan kurang lebih 4 bulan maka diketahui terjadi peningkatan pengetahuan petani tentang penerapan teknologi kakao sehat rata-rata sebesar $72,22 \%$ dan keterampilan sebesar $67,5 \%$. Hingga saat ini terdapat peningkatan volume buah baik secara kuantitas maupun kualitas yang diperlihatkan oleh peningkatan jumlah bakal buah/pohon $(36,68 \%)$, jumlah buah/pohon (20\%), dan berat kering biji/pohon (30,2\%). Peningkatan pengetahuan dan keterampilan dalam penerapan teknologi kakao sehat oleh kelompok tani "Wonga Mengi" telah berdampak pada peningkatan produksi kakao.
\end{abstract}

Kata Kunci : keterampilan, pegetahuan, produksi kakao, teknologi kakao sehat.

\section{ABSTRACT}

Kedibodu Village is located $12 \mathrm{~km}$ from the capital city of Ende Regency, which is part of the population earning a living as a cocoa farmer. The average land area of cocoa farmers is \pm 2 ha/person with average productivity of $140 \mathrm{~kg} / \mathrm{ha}$ which is very far from the ideal cocoa potential of 1,150 - 2,000 kg/ha. This condition is caused by the age of cocoa plants that are no longer productive, lack of care and high levels of pests and diseases. The service activity aims to increase the knowledge and skills of cocoa farmers in applying healthy cocoa technology so that the production of cocoa plants, especially in the "Wonga Mengi" farmer group in the village of Kedibodu, can be increased. The method used is participatory in the form of field schools by providing material and its application directly in the garden. There are two main program activities, namely providing direct assistance in the form of superior cocoa seedlings in the form of cuttings or entries and pruning tools as well as providing assistance in the application of healthy cocoa technology. After mentoring for about 4 months, it is known that there is an increase in farmers' knowledge about the application of healthy cocoa technology by an average of $72.22 \%$ and skills by $67.5 \%$. Until now there has been an increase in fruit volume both in quantity and quality, which is shown by an increase in the number of ovaries/trees (36.68\%), the number of fruits/trees (20\%), and the dry weight of seeds/trees (30.2\%). With this service, an increase in the knowledge and skills of the "Wonga Mengi" farmer group in implementing healthy cocoa technology has an impact on increasing cocoa production.

Keywords: skills, knowledge, cocoa production, healthy cocoa technology 


\section{PENDAHULUAN}

Desa Kedebodu berjarak $\pm 12 \mathrm{~km}$ dari kota Ende dengan luas wilayah 762,1 ha dan memiliki jumlah penduduk 671 jiwa. Dari total jumlah penduduk, 154 KK merupakan petani kakao dengan total luas garapan seluas 347 ha (BPPS.Ende, 2016). Kondisi topografi wilayah yang mendukung bagi pertumbuhan kakao menjadikan desa ini sebagai salah satu desa di kabupaten Ende yang berpotensi menjadi desa pengembangan tanaman Kakao. Berdasarkan hasil survei diketahui bahwa rata - rata petani memiliki areal pertanaman kakao seluas 2 $\mathrm{Ha}$ /orang dengan produktivitas sebanyak $140 \mathrm{~kg} / \mathrm{ha}$ (biji kakao kering). Kondisi tersebut sangat jauh dibawah potensi produktivitas kakao seharusnya yaitu $1.150-2.000 \mathrm{~kg} / \mathrm{ha}$ (Siswanto, 2012; Murtiningrum dan Bantacut, 2016; Manalu, 2018). Hasil pendataan tim berkenaan dengan pendapatan petani yang diperoleh dari penjualan kakao dari lima kelompok tani di desa Kedebodu (Wonga Mengi, Jopu Ju, Wolondopo, Watumaru, dan Bungu Jumu) perbulan rata rata Rp.370.000 dan digunakan untuk menghidupi rata - rata 5 orang dalam satu keluarga. Penghasilan tersebut sangat kurang jika dibandingkan dengan hasil seharusnya yang dapat diperoleh dari tanaman kakao yang dibudidayakan dengan baik.

Kelompok tani Wonga Mengi yang beranggotakan 20 orang memiliki total luas lahan garapan seluas $\pm 20 \mathrm{Ha}$ (kakao dan sirih), 17 orang diantaranya kurang paham tentang budidaya kakao yang baik. Rata - rata tanaman kakao tidak dipangkas menyebabkan petani sulit menjangkau buah pada saat panen. Akibat lainnya adalah buruknya kondisi lingkungan mikro yang sangat mengutungkan bagi perkembangan hama dan penyakit seperti hama penggerek buah kakao (Conopomorpha cramerella), penghisap buah kakao (Helopeltis spp) dan busuk buah kakao (Phytoptora palmivora) (Murtiningrum \& Bantacut, 2016; Masnilah, 2019). Akibat dari serangan hama dan penyakit tersebut, hasil kakao dapat menurun hingga $70-100 \%$ (Siswanto, 2012). Teknik pemanenan yang tidak benar mengakibatkan buah kakao tidak muncul kembali pada musim buah berikutnya (Rubiyo, 2012; Masnilah, 2019) karena buah kakao hanya muncul pada bagian cabang tertentu saja. Tanaman kakao yang dibudidayakan oleh petani rata - rata telah melampaui usia produktif dan tidak pernah dilakukan peremajaan. Sanitasi dan pemupukan tidak pernah dilakukan, bahkan kulit kakao yang telah didipanen berserakan di kebun - kebun petani dan menjadikan pestisida sintetik sebagai satu-satunya cara yang efektif dalam memberantas hama.

Fenomena tersebut menjadi permasalahan utama karena kegiatan perbaikan teknik budidaya menjadi penentu untuk mendapatkan kuantitas dan kualitas yang baik sesuai permintaan pasar. Jika kuantitas dan kualitas produksi kakao baik maka menjadi lebih mudah untuk melakukan inovasi dalam pengembangan produk dan kegiatan pemasaran. Oleh sebab itu, tujuan dari kegiatan pengabdian masyarakat stimulus ini adalah untuk meningkatkan pengetahuan dan keterampilan mitra dalam penerapan teknologi kakao sehat yang pada akhirnya terjadi peningkatan produksi tanaman kakao.

\section{METODE}

Pengabdian Kemitraan Masyarakat Stimulus (PkMS) melalui penerapan Teknologi kakao sehat dilakukan dengan prinsip pemberdayaan petani melalui metode Sekolah Lapang. Sekolah lapang merupakan suatu metode penyuluhan yang memadukan teori dan pengalaman petani dalam melakukan kegiatan usaha tani (Slameto, 2014; Evizal et al., 2017). Metode sekolah lapang yang terdiri dari kegiatan penyuluhan, praktek langsung, pendampingan serta memberikan kesempatan kepada peserta untuk turut serta dalam melakukan monitoring dan evaluasi sehingga peserta dapat menarik kesimpulan dan mengambil keputusan yang tepat dalam menentukan pengelolaan kebun mereka selanjutnya menjadikan petani sebagai seorang yang ahli dalam manajemen pengelolaan kebunnya (Firmana dan Nurmalina, 2016; Khairul et al., 2018; Hexa et al., 2019). Metode ini telah terbukti dapat meningkatkan pengetahuan, pemahaman, keterampilan petani bahkan meningkatkan pendapatan petani melalui peningkatan produksi (Firmana dan Nurmalina, 2016; Slameto, 2014). Oleh sebab itu, metode sekolah lapang menjadi pilihan yang dianggap tepat untuk menyelesaikan permasalahan petani kakao di Desa Kedebodu saat ini, dengan memberikan pemahaman tentang konsep ekologi dan sumberdaya alam dan manusia yang benar serta dengan melakukan praktek langsung di kebun bersama petani diharapkan petani mampu menyerap pengetahuan dan mengasah keterampilan dalam teknologi kakao sehat 
seperti analisis ekosistem tanaman kakao, nutrisi tanah dan tanaman kakao, pengenalan hama dan penyakit penting tanaman kakao dan teknik pengendaliannya, pembuatan pestisida nabati dan perangkap hama, pembuatan pupuk organik dan rorak di kebun, teknik panen dan pasca panen.

Sekolah lapang dilakukan sebanyak 12 kali pertemuan dengan mengukur peningkatan pengetahuan dan keterampilan petani melalui kegiatan pre-test dan post-tes yang kemudian hasilnya akan di analisis melalau skala linkret. Selama 6 bulan dilakukan monitoring untuk mengetahui keberhasilan program. Peningkatan produksi diukur melalui perbandingan banyaknya komponen produksi sebelum dan setelah dilakukan penerapan teknologi kakao sehat. Seluruh kegiatan di evaluasi secara bersama-sama dengan anggota kelompok yang hasilnya menjadi rekomendasi dalam kegiatan selanjutnya.

\section{HASIL DAN PEMBAHASAN}

\section{Peningkatan Pengetahuan Petani terhadap Teknologi Kakao Sehat}

Kegiatan Sekolah Lapang ini dimulai dari bulan Februari - September 2019, target utama pada pelaksanaan PkM ini adalah peningkatan produksi tanaman kakao dengan melakukan pemberdayaan anggota kelompok dengan memberikan pengetahuan dan keterampilan yang memadai dalam menerapkan teknologi kakao sehat. Sebanyak 20 orang petani kakao diberikan pelatihan dan praktek langsung pada kebun contoh, sebelumnya petani diajak untuk melihat kebun Kakao yang telah menerapkan teknologi kakao sehat dengan harapan para anggota kelompok dapat membandingkan kebun kakao yang sehat dan tidak. Persentase peningkatan pengetahuan petani tentang teknologi kakao sehat yang meliputi 9 kriteria pertanyaan (Gambar 1) yang dianalisis berdasarkan hasil pre-test dan post-tes (Gambar 2.). Pertanyaan-pertanyaan yang diberikan meliputi seluruh pengetahuan tentang penerapan teknologi kakao sehat. Secara lengkap hasil analisis peningkatan pengetahuan petani dapat dilihat pada Gambar 1.

Gambar 1. Memperlihatkan rata-rata peningkatan pengetahuan petani terhadap 9 kriteria pertanyaan adalah $72,22 \%$. Peningkatan pengetahuan tentang pemangkasan bentuk dan produksi pada tanaman kakao memperoleh nilai terendah sebesar $50 \%$, kondisi ini disebabkan oleh kebiasaan petani yang tidak melakukan perawatan pada tanaman kakao dan keengganan petani untuk melakukan pemangkasaan apabila pohon kakao sedang berbuah. Namun demikian persentase peningkatan pengetahuan tertinggi terjadi pada kriteria pemanfaatan limbah kakao sebesar $93,75 \%$. Pada kriteria tersebut diketahui bahwa petani tidak pernah memanfaatkan limbah kakao baik berupa seresah daun, ranting ataupun buah, namun setelah program petani menjadi tahu bahwa limbah kakao dapat dijadikan pupuk ataupun sebagai pakan ternak. Peningkatan pengetahuan tersebut juga didukung oleh kegiatan Sekolah Lapang yang dilakukan oleh Khairul et al., (2018) pada kelompok tani kakao di Kanagarian, Padang Pariaman dan Slameto (2014) di Lampung.

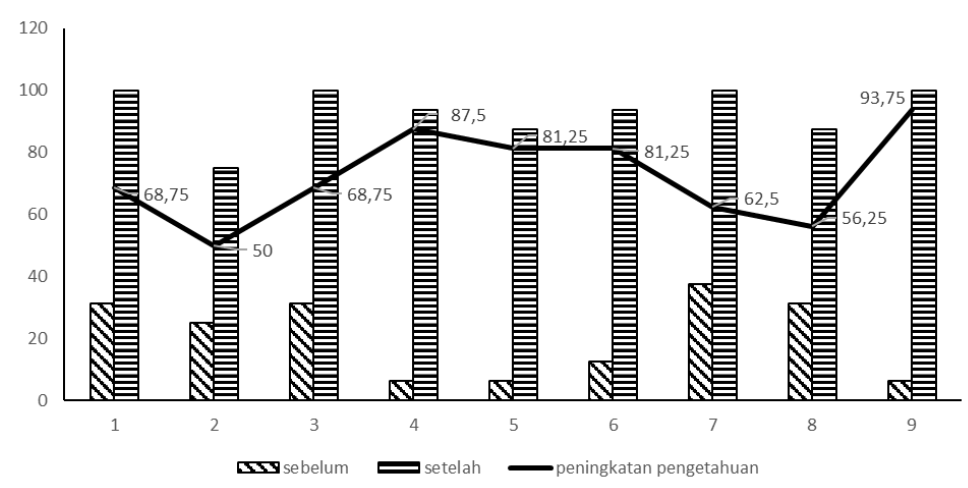

Gambar 1. Persetase peningkatan pengetahuan petani tentang teknologi kakao sehat

Keterangan : Persentase peningkatan pengetahuan petani tentang : 1) ekosistem kebun kakao sehat, 2) teknik pemangkasan bentuk dan produksi, 3) pemupukan dan pembuatan rorak, 4) sanitasi kebun, 5) Jenis hama dan penyakit tanaman kakao, 6) teknik pengendalian hama dan penyakit kakao, 7) pembuatan pestisida nabati, 8) perlakuan panen dan pasca panen, 9) pemanfaatan limbah kakao 


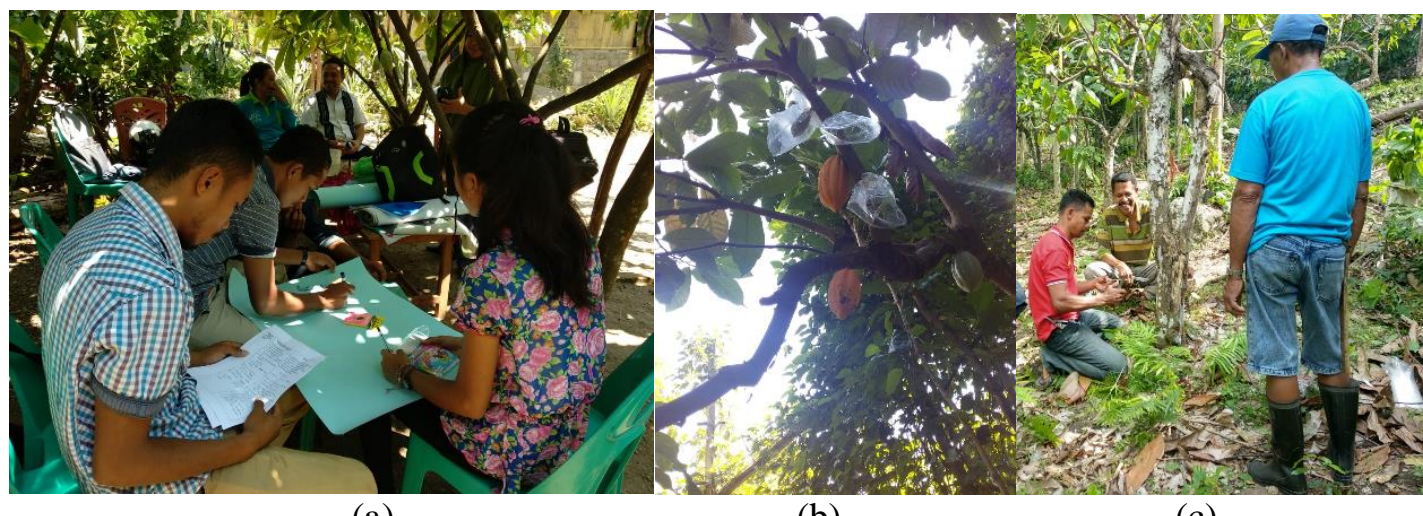

(a)

(b)

(c)

Gambar 2. Kegiatan analisis ekosistem (a), pemasangan sarungnisasi (b), Sambung samping (c)

Kendala yang dihadapi tim pada saat melakukan kegiatan pre-test dan post-tes ini adalah $45 \%$ anggota kelompok tidak dapat membaca dan menulis sehingga anggota tim turut serta dalam menjelaskan isi dari pertanyaan yang diajukan.

\section{Peningkatan Keterampilan Petani dalam Penerapan Teknologi Kakao Sehat}

Peningkatan keterampilana petani dalam menerapkan teknologi kakao sehat diukur sebagai suatu keberhasilan apabila petani mampu menerapkan 10 kriteria keterampilan yang diajarkan dengan baik (Gambar 3).
Peningkatan keterampilan petani cenderung lebih rendah $(67,5 \%)$ jika dibandingkan dengan peningkatan pengetahuannya $(72,22 \%)$. Kondisi yang sama juga terjadi pada beberapa sekolah lapang petani kakao (Slameto, 2014; Zakil M et al., 2017; Khairul et al., 2018). Keterampilan yang memadai diperoleh dengan cara mengasah kemampuan terus menerus, sementara itu program PkMS hanya berlangsung dalam waktu yang terbatas, oleh sebab itu pendampingan dan pemantauan setelah program wajib dilakukan. Berikut disajikan data persentase peningkatan keterampilan petani kelompok "Wonga Mengi" dalam menerapkan teknologi kakao sehat.

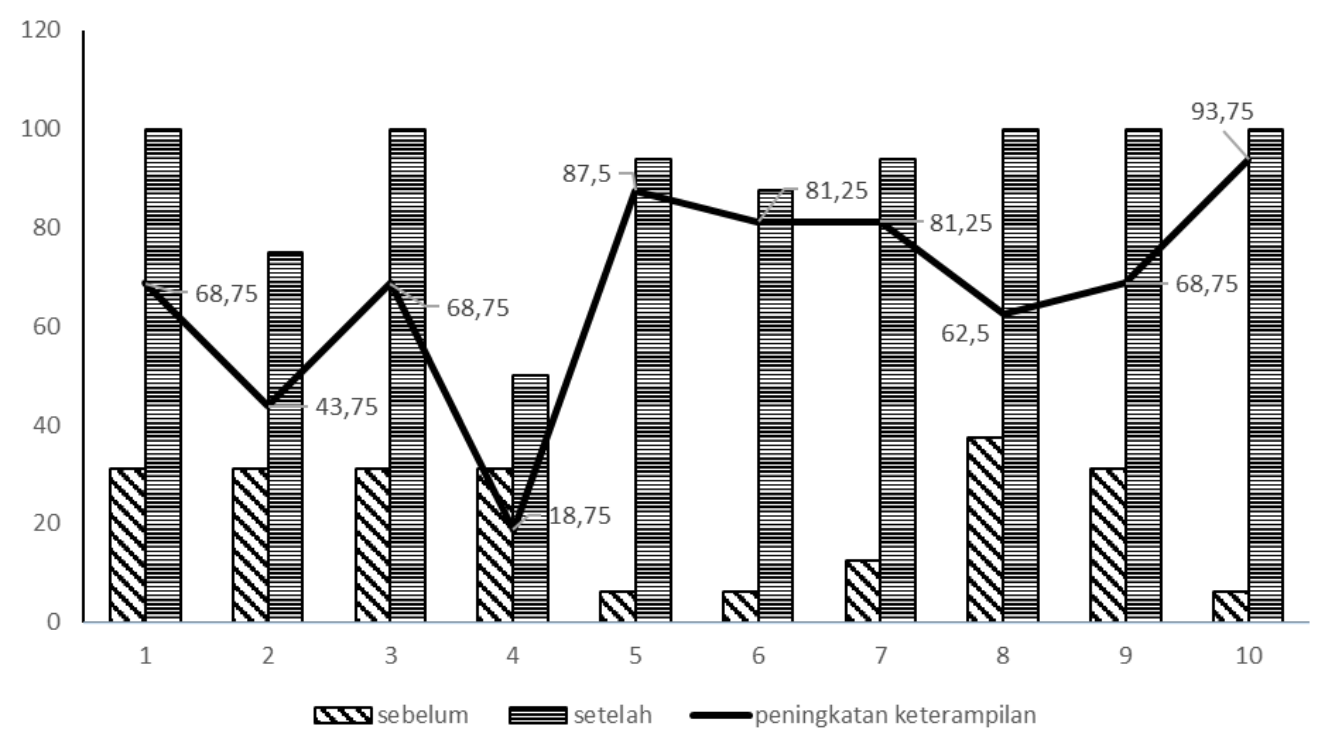

Gambar 3. Persentase peningkatan keterampilan petani kakao dalam menerapkan teknologi kakao sehat

Keterangan : Persentase peningkatan keterampilan petani tentang : 1) analisis ekosistem kebun kakao sehat, 2) teknik pemangkasan bentuk dan produksi, 3) sambung pucuk dan sambung samping, 4) pemupukan dan pembuatan rorak, 5) sanitasi kebun, 6) Jenis hama dan penyakit tanaman kakao, 7) teknik pengendalian hama dan penyakit kakao, 8) pembuatan pestisida nabati, 9) perlakuan panen dan pasca panen, 10) pemanfaatan limbah kakao 
Gambar 3. Memperlihatkan bahwa persentase peningkatan keterampilan petani dalam menerapkan teknologi kakao sehat paling rendah $(18,75 \%)$ terjadi pada kegiatan sambung pucuk dan sambung samping. Pada kegiatan sambung pucuk dan sambung samping menjadi kegiatan yang relative sulit diterapkan oleh petani karena pada kegiatan ini kondisi alat menjadi penentu dimana pisau okulasi harus benar-benar tajam dan dalam kondisi yang steril, selain itu sayatan pada entris ataupun pada pohon dan bibit harus benar-benar tepat (Angela dan Efendi, 2015). Kegiatan sambung pucuk dan sambung samping ini merupakan kegiatan penentu dalam keberhasilan kegiatan peremajaan ataupun rehabilitasi tanaman kakao. Namun demikian kegiatan seperti sanitasi kebun, pengenalan jenis hama dan penyakit kakao, pembuatan pestisida dan pemanfaatan limbah kakao mendapatkan nilai di atas $80 \%$ yang artinya bahwa petani dalam tingkatan mahir. Pencapaian yang sama juga diungkapkan oleh Khairul et al. (2018) yang menyatakan bahwa melalui Sekolah Lapang Hama Terpadu dapat meningkatkan keterampilan petani dalam pembuatan pestisida nabati, pembuatan perangkap dan kegiatan sarungnisasi.

\section{Peningkatan Produksi Tanaman Kakao melalui Penerapan Teknologi Kakao Sehat Parameter keberhasilan program} selanjutnya adalah peningkatan produksi kakao yang diukur pada 10 sampel tanaman yang telah diberi perlakuan penerapan teknologi kakao sehat. Parameter produksi tersebut adalaha jumlah tandan bunga/pohon, jumlah bakal buah/pohon, jumlah buah/pohon dan berat kering biji/pohon. Berikut disajikan rataan peningkatan produksi per pohon kakao yang telah menerapkan teknologi kakao sehat.

Tebel 1. Rataan peningkatan produksi per pohon kakao dengan penerapan teknologi kakao sehat

\begin{tabular}{lllll}
\hline No & Parameter Produksi & Sebelum pelaksanaan Program & $\begin{array}{l}\text { Setelah } \\
\text { Program }\end{array}$ & Pelaksanaan \\
\hline 1. & Jumlah tandan bunga & 7 tandan & 4 tandan & \\
2. & Bakal buah & 6 buah & 13 buah & \\
3. & Jumlah buah & 6 buah & 9 buah & \\
4. & Berat biji kering & $0,6 \mathrm{~kg}$ & $0,86 \mathrm{~kg}$ & \\
\hline
\end{tabular}

Tabel 1 memperlihatakan kondisi tanaman kakao sebelum dan setelah diterapkan teknologi kakao sehat. Setelah dilakukan pemangkasan jumlah tandan bunga mengalami penurunan, kondisi ini disebabkan beberapa tandan bunga pada pohon kakao ikut terpangkas karena berada pada area batang yang seharusnya dihilangkan, namun demikian dari rata-rata 4 tandan bunga yang muncul dapat menghasilkan bakal buah (13 bakal buah) dan buah (9 buah) yang lebih banyak dibandingkan pada saat sebelum dilakukan pemangkasan. Kondisi tersebut menandakan bahwa asupan nutrisi tanaman telah terfokus pada pembentukan buah dan tidak dihabiskan oleh cabang atau rantingranting (Angela, 2019). Hal ini sesuai dengan fungsi dari pemangkasan yaitu agar tanaman tidak kehilangan nutrisinya dan memicu tanaman untuk membentuk daun baru yang berimbas pada peningkatan kualitas buah (Baihaqi et al., 2015). Selain akibat dari pemangkasan, adanya rorak atau lubang tempat penimbunan serasah disekitar pertanaman yang secara alami telah menyediakan bahan organic yang dapat menyimpan air dengan baik (Bone, 2017) serta menghasilkan nutrisi bagi tanaman
(Agussalim, 2016) sehingga kebutuhan akan air dan nutrisi tanaman terpenuhi sepanjang waktu. Peningkatan produksi kakao juga diperlihatkan dari peningkatan berat biji kering sebesar 30,2\% dari berat biji 0,6 kg/pohon sebelum dilakukan pemangkasan menjadi $0,86 \mathrm{~kg} /$ pohon setelah dilakukan pemangkasan. Tentunya peningkatan produksi semakin lama semakin meningkat seiring dengan kesiapan tanaman dalam memproduksi buah secara baik. Dengan meningkatnya produksi biji kakao maka tentunya akan berimbas pada peningkatan pendapatan petani kakao kelompok "Wongan Mengi" di Kecamatan Ende Selatan Kabupaten Ende Propinsi Nusa Tenggara Timur. Sementara itu, Firmana dan Nurmalina (2016) menerangkan bahwa adanya hubungan antara pelaksanaan sekolah lapanag dengan peningkatan pendapatan usaha tani di Karawang

\section{KESIMPULAN}

Kegiatan pemberdayaan anggota kelompok "Wonga Mengi" di Desa Kedibodu sudah berhasil mengatasi permasalahan rendahnya produktivitas kakao yang disebabkan 
oleh umur tanaman yang sudah tidak produkstif, kurangnya perawatan dan tingginya serangan hama dan penyakit. Kegiatan dilaksanakan dengan penerapan teknologi kakao sehat yang menitikberatkan pada perbaikan ekosistem tanaman kakao dan rehabilitasi tanaman. Kegiatan telah berhasil meneningkatkan pengetahuan petani sebesar $72,22 \%$ dan keterampilan sebesar $67,5 \%$. Rendahnya produksi tanaman telah dapat diatasi. dengan semakin meningkatnya jumlah komponen produksi pada setiap tanaman yaitu peningkatan jumlah bakal buah/pohon 36,68\%, jumlah buah/pohon $20 \%$ dan berat kering biji/pohon $30,2 \%$. Peningkatan pengetahuan dan keterampilan dalam penerapan teknologi kakao sehat telah berdampak pada peningkatan produksi kakao.

\section{UCAPAN TERIMA KASIH}

Penulis mengucapkan terimakasih yang sebesar-besarnya kepada Kemenristek Dikti yang telah memberikan dukungan pendanaan melalui Hibah Pengabdian Kepada Masyarakat Stimulus di bawah Koordinasi LP2M Uniersitas Flores yang diperkuat dengan kontrak No. 85/115/F-12/N/2019. Terimakasih juga penulis sampaikan kepada Bapak Kepala Desa Kedibodu dan Ketua Kelompok Wonga Mengi atas kerjasama baiknya.

\section{DAFTAR PUSTAKA}

Agussalim. (2016). Efektivitas Pupuk Organik Terhadap Produktivitas Tanaman Kakao di Sulawesi Tenggara. Jurnal Pengkajian Dan Pengembangan Teknologi Pertanian. https://doi.org/10.21082/jpptp.v19n2.201 6.p167-176

Angela. (2019). Pengelolaan pemangkasan kakao. Journal of Chemical Information and Modeling, 53(9), 1689-1699. https://doi.org/10.1017/CBO9781107415 324.004

Angela\& Efendi, D. (2015). Pengelolaan Pemangkasan Tanaman Kakao (Theobroma Cacao L.) Di Cilacap, Jawa Tengah. Buletin Agrohorti. https://doi.org/10.29244/agrob.3.3.285293

BPPS Ende. 2016. Potensi Tanaman Perkebunan Kabupaten Ende. https://endekab.bps.go.id/subject/54/perk ebunan.html\#subjekViewTab3
Baihaqi, A., Hamid, A., Anhar, A., Abubakar, Y., Anwar, T., \& Zazunar, Y. (2015). Penerapan Teknik Budidaya Serta Hubungan Antara Pemangkasan Dan Peningkatan Kesuburan Tanah Terhadap Peningkatan Produktivitas Kakao Di Kabupaten Pidie. Jurnal Agrisep, 16(2), 54-61.

https://media.neliti.com/media/publicatio ns/13209-ID-penerapan-teknik-budidayaserta-hubungan-antara-pemangkasandan-peningkatan-kesu.pdf

Bone, K. (2017). Pemanfaatan limbah kulit buah kakao sebagai pupuk organik di kecamatan lamuru kabupaten bone. Jurnal Balireso.

Evizal, R., Prasmatiwi, F. E., Wibowo, L., \& Rahmawati, W. (2017). Mendorong Rehabilitasi Kebun Secara Mandiri. http://repository.lppm.unila.ac.id/5287/1/ RusdiEvizalSemAbdi2017.pdf

Firmana, F., \& Nurmalina, R. (2016). Dampak Penerapan Program SLPTT terhadap Pendapatan Usahatani Padi di Kecamatan Telagasari Kabupaten Karawang. Agrikultura.

https://doi.org/10.24198/agrikultura.v27i 1.8475

Hexa, H., Maman, U., \& J, J. (2019). Efektivitas Penyuluhan Metode Sekolah Lapang Terhadap Penerapan Standar Operasional Prosedur (SOP) Budidaya Anggrek Tanah (Teresterial) di Kota Tangerang Selatan. AGRIBUSINESS JOURNAL. https://doi.org/10.15408/aj.v11i1.11832

Khairul, U., Trizelia, T., \& Reflin, R. (2018). Pemberdayaan Kelompok Tani Melalui Pelatihan Pengendalian Hama dan Penyakit Tanaman Kakao di Kanagarian Campago Kabupaten Padang Pariaman. BULETIN ILMIAH NAGARI MEMBANGUN.

https://doi.org/10.25077/bnm.1.4.88-95.0 Manalu, R. (2018). UNTUK MENINGKATKAN PENDAPATAN PETANI ( Processing of Smallholder Plantations Cocoa Production to Increase Farmers Income ). 99-111. jurnal.dpr.go.id > index.php > ekp $>$ article > download

Masnilah. (2019). ORGANISME PENGANGGANGGU. Pnh 1503. https://www.academia.edu/40591975/Pen yakit_Pada_Tanaman_Kakao_dan_Tekni k_Pengendaliannya

Murtiningrum, M., \& Bantacut, T. (2016). 
Review : Potensi Dan Arah Pengembangan Agroindustri Berbasis Kakao Di Provinsi Papua Barat. Agrointek, $\quad$ 10(1), 1. https://doi.org/10.21107/agrointek.v10i1. 2020

Rubiyo. (2012). Peningkatan Produksi dan Pengembangan Kakao ( Theobroma cacao L. ) di Indonesia. Jurnal Tanaman Industri Dan Penyegar - Journal of Industrial and Beverages Crops Research, 3(1), 33-48. https://doi.org/10.21082/jtidp.v3n1.2012. p33-48

Siswanto. (2012). Pengendalian-Hama-UtamaKakao. 11(2), 103-112. http://perkebunan.litbang.pertanian.go.id/ dbasebun/asset_dbasebun/Penerbitan20141207121322.pdf
Slameto. (2014). Efektivitas Proses Pembelajaran Sekolah Lapang Oleh Komunitas Petani Di Lampung. Jurnal Agro Ekonomi, 32(1), 35-55. https://www.researchgate.net/publication/ 313932327_Efektivitas_Proses_Pembelaj aran_Sekolah_Lapang_Pengelolaan_Tan aman_Terpadu_Padi_Sawah_oleh_Komu nitas_Petani_di_Lampung/link/58b0390a aca2725b5413cafb/download

Zakil M, A. D., Rusman, Y., \& Yusuf, M. N. (2017). Dampak Sekolah Lapang Pengendaaliaan Hama Terpadu (SLPHT) Terhadap Tingkat Penerapan Teknologi Pengendalian Hama Terpadu (PHT) Padas Usah Tani Padi Sawah (Oryza Sativa L.). JURNAL ILMIAH MAHASISWA AGROINFO GALUH. https://doi.org/10.25157/jimag.v1i1.285 